\title{
PENTINGNYA PENGGUNAAN PROGRAM APLIKASI INSTRUMENTASI DATA UNTUK MENGGALI ARAH PEMINATAN PESERTA DIDIK SMP DI KABUPATEN PAMEKASAN
}

\author{
Agus Supriyadi \\ Institut Agama Islam Al Khairat Pamekasan \\ Email: abahagus65@gmail.com
}

\begin{abstract}
With so many tasks that must be completed cultivated fields by teachers Guidance and Counseling which consists of four fields, eleven types of services, and six support units. The teacher then Guidance and Counseling feel overwhelmed and unable to complete the task becomes all areas mandate, particularly in data collection and usage instrumentation applications. Unfinished inability to complete all the administrative tasks of the Guidance and Counseling teacher, now coupled with new task field known as Direction Specialisation, which according to teachers Guidance and Counseling " jobs that seem more time-consuming, and difficult to resolve in a short time ". So that guidance and counseling teacher performance was not optimal. In this research method is discussed about the development, stages, testing, and analysis products. To obtain the necessary data, the researchers chose 20 people teachers Guidance and Counseling are incorporated in MGBK (Musyawarah Guru Bimbingan dan Konseling; Deliberation Teacher Guidance and counseling) Pamekasan as test subjects with treatment instrumentation applications utilizing the data direction of specialization. With this treatment were then given a questionnaire to determine the performance associated with speed and ease before and after using the instrumentation application of data toward specialization

From the results of this development was obtained performance without using a program based on the pace of work $=38: 80=0.475$ or $47.5 \%$ of the expected criteria. From the aspects of ease in working $=38: 80=0.475$ or $47.5 \%$ of the expected criteria. While using the application program instrumentation toward specialization junior learners views on aspects of the system working speed $=66: 80=0.825$ or 82.5 $\%$ of that expected. Ease in working $=65: 80=0.8125$ or $81.25 \%$ of the expected. For the lowest working system is the convenience aspect, which reached $81.25 \%$ of the expected. From the calculation we can conclude the difference between a working system without and with using the program. So that the application program instrumentation specialization direction data can be harnessed and used by teachers Guidance and Counseling in Pamekasan to improve performance in the implementation of the service. Suggestions can be submitted to the user program the data instrumentation applications, especially towards specialization learners in making its recommendation sheet, to be able to properly and optimally utilize it possible to increase the performance of services to students of teaching.
\end{abstract}

Keywords: Instrumentation applications, improve the performance, Students 
Abstrak: Dengan banyaknya tugas bidang garapan yang harus diselesaikan oleh Guru Bimbingan dan Konseling yang terdiri dari empat bidang, sebelas jenis layanan, dan enam satuan pendukung. Maka Guru Bimbingan dan Konseling merasa kewalahan dan tidak sanggup untuk menyelesaikan semua bidang tugas yang menjadi amanatnya, khususnya dalam penghimpunan data dan penggunaan aplikasi instrumentasi. Belum selesai ketidaksanggupan menyelesaikan semua administrasi yang menjadi tugas Guru BK tersebut, sekarang ditambah lagi dengan bidang tugas baru yang dikenal dengan Arah Peminatan, yang menurut Guru Bimbingan dan Konseling "pekerjaan yang sepertinya lebih memakan waktu, dan sulit untuk diselesaikan dalam waktu singkat". Sehingga kinerja Guru Bimbingan dan Konseling tidak maksimal. Dalam metode penelitian ini dibahas tentang pengembangan, tahapan, uji, dan analisa penggunaan. Untuk memperoleh data yang diperlukan, peneliti memilih 20 orang Guru Bimbingan dan Konseling yang tergabung dalam MGBK (Musyawarah Guru Bimbingan dan konseling) Kabupaten Pamekasan sebagai subyek uji dengan perlakuan memanfaatkan aplikasi instrumentasi data arah peminatan. Dengan perlakuan tersebut kemudian diberikan angket untuk mengetahui kinerja yang berhubungan dengan kecepatan dan kemudahan sebelum dan sesudah menggunakan aplikasi instrumentasi data arah peminatan.

Dari hasil penelitian pengembangan ini diperoleh kinerja tanpa menggunakan program berdasarkan kecepatan kerja $=38: 80=0,475$ atau $47,5 \%$ dari kriteria yang diharapkan. Dari aspek kemudahan dalam bekerja $=38: 80=0,475$ atau 47,5 $\%$ dari kriteria yang diharapkan. Sedangkan dengan menggunakan program aplikasi instrumentasi arah peminatan peserta didik SMP dilihat pada aspek kecepatan kerja sistem $=66: 80=0,825$ atau $82,5 \%$ dari yang diharapkan. Kemudahan dalam bekerja $=65: 80=0,8125$ atau 81,25 \% dari yang diharapkan. Untuk sistem kerja yang terendah adalah pada aspek kemudahan, yaitu baru mencapai $81,25 \%$ dari yang diharapkan. Dari perhitungan dapat disimpulkan adanya perbedaan antara sistem kerja tanpa dan dengan menggunakan program. Sehingga program aplikasi instrumentasi data arah peminatan dapat dimanfaatkan dan digunakan oleh Guru Bimbingan dan Konseling di Kabupaten Pamekasan untuk dapat meningkatkan kinerja dalam pelaksanaan layanan. Saran yang dapat disampaikan pada pemakai program aplikasi instrumentasi data arah peminatan peserta didik khususnya dalam pembuatan lembar rekomendasinya, untuk dapat memanfaatkan dengan baik dan seoptimal mungkin untuk peningkatan kinerja layanan kepada peserta didik yang diampu.

Kata kunci: Aplikasi instrumentasi, meningkatkan kinerja, Peserta Didik 
PENDAHULUAN

Guru BK atau konselor sekolah yang mempunyai tugas memberikan layanan Bimbingan dan Konseling yang terjadwal dan tidak terjadwal, juga harus mempunyai kemampuan dan pengetahuan untuk mengoperasikan perangkat komputer, lebih-lebih dalam pelaksanaan layanan dan penghimpunan data peserta didik/konseli yang menjadi anak asuhnya. Karena kita tahu bahwa tugas dari Guru BK/Konselor meliputi beberapa aspek kerja , mulai dari membuat program, pelaksanaan program, evaluasi, pelaporan, serta tindak lanjutnya.

\begin{tabular}{lcr}
\multicolumn{1}{c}{ Dengan } & bantuan & perangkat \\
komputer, & kemampuan & Guru \\
BK/Konselor & dapat & lebih \\
efisiensertamemudahkan & dan
\end{tabular}

memperlancar pelaksanaan layanan termasuk di dalamnya menghimpun data peserta didik/konseli yang diasuhnya. Karena tidak mungkin serorang guru BK/Konselor tanpa bantuan perangkat komputer dapat menghimpun data peserta didik/konseli yang menjadi anak asuhnya yang begitu banyak yakni 150-160 dapat terlaksana secara optimal.

Pelaksanaan layanan yang selama ini dikerjakan oleh guru BK/Konselor banyak dilakukan secara manual disebabkan oleh terbatasnya kemampuan yang dimiliki oleh masingmasing individu. Hal ini dimungkinkannya ketrebatasan kompetensi yang dimiliki oleh Guru BK/Konselor yang ada di Indonesia secara umum. Sebagaimana yang dikemukakan oleh Drs. H. Sutijono,M.M. (Dalam Materi Umum Pendidikan dan Latihan Profesi Guru 2010 : 2) bahwa : "Saat ini baru $50 \%$ dari seluruh guru di Indonesia yang memiliki standarisasi dan kompetensi. Keadaan seperti ini masih kurang. Sehingga mutu pendidikan kita belum menunjukkan peningkatan yang signifikan."

Program dan pelaksanaan layanan Bimbingan Konseling yang selama ini telah menjadi tugas rutin dan telah dilakukan Guru BK/Konselor terdiri dari : layanan orientasi, layanan dasar, layanan responsip, layanan perencanaan individual, dukungan sistem, alih tangan kasus, aplikasi instrumen bimbingan, himpunan data, konfrensi kasus, dan kunjungan rumah.

Arah peminatan Peserta Didik yang diperkenalkan dalam Implementasi Kurikulum 2013 merupakan informasi baru bagi Guru BK/Konselor. Dalam pelaksanaan di lapangan banyak guru BK/Konselor belum paham maksud dan tujuan pelaksanaan/penerapan yang akan disampaikan kepada peserta didik/konseli serta hasil yang akan diperoleh.

Guru BK/Konselor mengalami kesulitan untuk menerapkan/melaksanakan layanan arah peminatan Peserta Didiktersebut, khususnya dalam pembuatan "Lembar Format Rekomendasi" nya.Yang menjadi permasalahan yang mendasar bagi Guru BK/Konselor dalam pelaksanaan layanan Bimbingan dan Konseling arah peminatan peserta didik adalah kecepatan kerja, penggunaan tivitas kerja, dan kenyamanan kerja yang kurang maksimal. Untuk itu diperlukan pengembangan aplikasi instrumentasi yang dapat membantu kinerja pelaksanaan layanan Bimbingan dan Konseling arah peminatan peserta didik sehingga pelaksanaan layanan dapat dicapai secara optimal.

\section{METODE}

Metode yang digunakan oleh peneliti yakni dengan menggunakan data kuantitatif yang berbentuk interval. Hal ini dimaksudkan untuk pengujian signifikansi peningkatan 
kinerja dalam sistem kerja pelaksanaan layanan Bimbingan dan Konseling tanpa menggunakan program aplikasi instrumentasi arah peminatan peserta didik, dan sistem kerja pelaksanaan layanan Bimbingan dan Konseling yang menggunakan program aplikasi instrumentasi arah peminatan peserta didik.

Instrumen penelitian untuk menguji penerapan penggunaan program aplikasi instrumentasi arah peminatan peserta didik menggunakan dua indikator, yang selanjutnya diberikan kepada responden yang telah melaksanakan layanan Bimbingan dan Konseling arah peminatan peserta didik tanpa menggunakan aplikasi instrumentasi arah peminatan.

Untuk membuktikan signifikansi dari pengembangan penggunaan aplikasi instrumentasi arah peminatan peserta didik, maka pengolahan data yang digunakan dalam penelitian ini dengan menggunakan analisa SPSS yakni paired sampel $t$ test (uji $t$ dua sampel yang berpasangan). uji t-Paired digunakan untuk menentukan ada tidaknya perbedaan rata-rata dua sampel bebas. Dua sampel bebas yang dimaksud adalah sampel yang sama namun mempunyai dua dat

\section{HASIL}

Berdasarkan analisis data dan untuk mengetahui peningkatan suatu kinerja dari penggunaan pengembangan program aplikasi instrumentasi data untuk menggali arah peminatan peserta didik SMP di Pamekasan tersebut, maka peneliti mengajukan angket tentang kinerja sistem kerja layanan bimbingan konseling tanpa menggunakan dan yang menggunakan program aplikasi instrumentasi arah peminatan peserta didik. Angket tersebut diberikan kepada 20 orang Guru Bimbingan dan Konseling/Konselor yang tergabung dalam Musyawarah Guru Bimbingan dan Konseling (MGBK) Kabupaten Pamekasan Tahun 2019-2020 yang dalam hal ini sebagai sampel, Guru BK, sekaligus pengguna program yang tahu persis apa dan bagaimana layanan arah peminatan peserta didik yang dilaksanakan di sekolah, maka dapat disajikan dalam bentuk data sebagai berikut :

Tabel: Perbandingan Kinerja Sistem Kerja Layanan Bimbingan Konseling Tanpa dan dengan Menggunakan Program Aplikasi Instrumentasi Data Arah Peminatan Peserta Didik

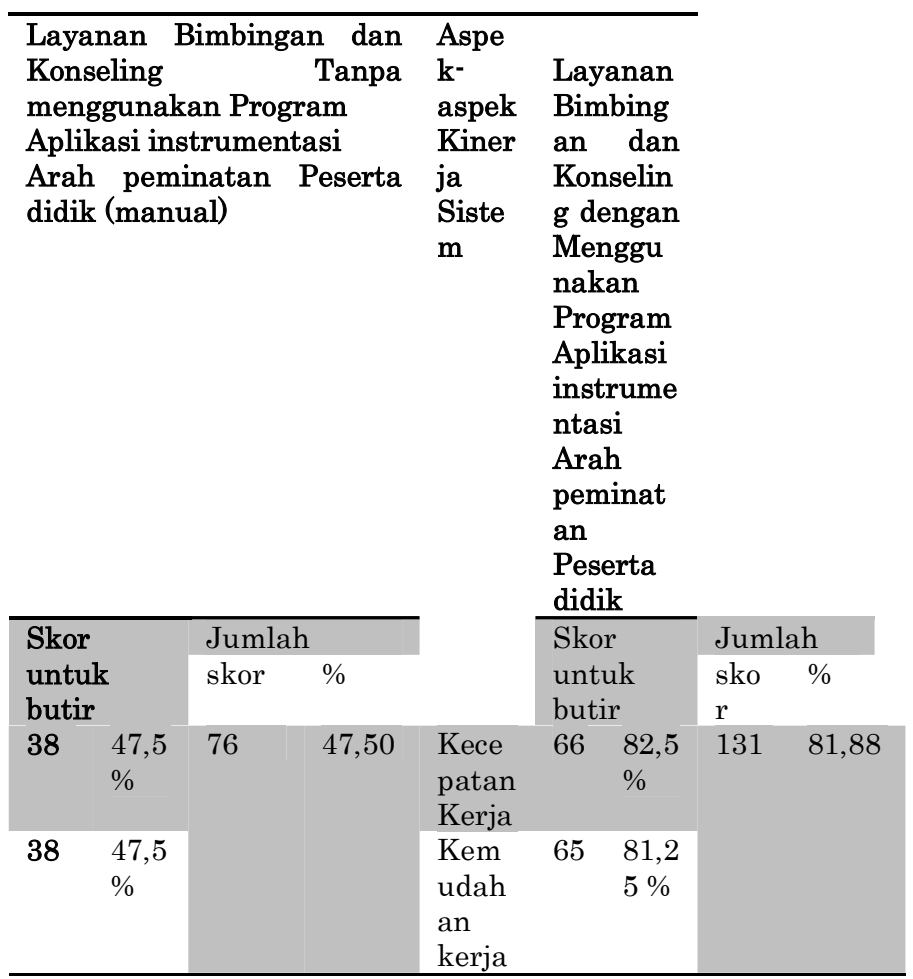

Sumber : Hasil perhitungan penyebaran angket penggunaan program aplikasi instrumentasi data untuk menggali arah peminatan peserta didik SMP kelas IX

Berdasarkan tabel di atas, kinerja tanpa menggunakan program aplikasi instrumentasi arah peminatan peserta didik SMP (secara manual) keseluruhan $=76: 160=0,475$ atau $47,5 \%$ dari kriteria yang diharapkan. Bila dilihat 
kinerja sistem kerja berdasarkan kecepatan kerja $=38: 80=0,475$ atau 47,5 \% dari kriteria yang diharapkan. Selanjutnya bila dilihat dari aspek kemudahan dalam bekerja $=38: 80=$ 0,475 atau 47,5 \% dari kriteria yang diharapkan. Jadi kinerja tanpa menggunakan program aplikasi instrumentasi data arah peminatan peserta didik, antara sistem kecepatan dan kemudahan dalam bekerja mencapai 47,5\% dari yang diharapkan.

Berdasarkan ketentuan tabel tersebut, maka kinerja dengan menggunakan program aplikasi instrumentasi arah peminatan peserta didik SMP secara keseluruhan = 131 : $160=0,81875$ atau 81,88 \% dari kinerja yang diharapkan. Dan apabila dilihat pada aspek kecepatan kerja sistem $=66$ : $80=0,825$ atau $82,5 \%$ dari yang diharapkan. Kemudahan dalam bekerja $=65: 80=0,8125$ atau 81,25\% dari yang diharapkan. Untuk sistem kerja yang terendah adalah pada aspek kemudahan, yaitu baru mencapai 81,25 $\%$ dari yang diharapkan.Dari perhitungan sudah terlihat adanya perbedaan antara sistem kerja tanpa dan dengan menggunakan program, dimana kinerja tanpa menggunakan program aplikasi instrumentasi data arah peminatan peserta didik (secara manual $)=47,5 \%$ dari yang diharapkan, dan kinerja dengan menggunakan program aplikasi instrumentasi data arah peminatan peserta didik $=81,88 \%$ dari yang diharapkan.

Berdasarkan tabel tersebut,
terlihat bahwa kinerja yang menggunakan program aplikasi instrumentasi data arah peminatan peserta didik jauh lebih tinggi dari kinerja tanpa menggunakan program aplikasi instrumentasi data arah peminatan peserta didik. Rata-rata sitem kerja tanpa menggunakan $($ manual $)=47,50 \%$ dan sistem kerja dengan menggunakan program $=81,88$ $\%$. Berdasarkan data tersebut terlihat bahwa sistem kerja yang menggunakan program aplikasi instrumentasi data arah peminatan peserta didik dapat meningkatkan kecepatan kerja, dan kemudahan dalam bekerja.

\section{PEMBAHASAN}

Perbedaan sistem kerja tanpa menggunakan program (manual) dan dengan menggunakan program aplikasi instrumentasi data arah peminatan peserta didik tersebut perlu diuji. Pengujian data dalam penelitian ini menggunakan analisa SPSS yakni Paired-Samples T Test (uji t dua sampel yang berpasangan). Paired Sampel t test ini digunakan untuk menentukan ada tidaknya perbedaan rata-rata dua sampel bebas, dan dua sampel yang dimaksud adalah sampel yang sama namun mempunyai dua data.

Adapun data-data yang akan dianalisa dengan menggunakan PairedSamples T Test adalah sebagai berikut : Data dari 20 responden yang melaksanakan layanan bimbingan konseling tanpa menggunakan program aplikasi instrumentasi arah peminatan peserta didik (manual) sebagai sampel $\mathrm{x}$. Dan yang telah melaksanakan layanan bimbingan konseling dengan menggunakan program aplikasi instrumentasi arah peminatan peserta didik sebagai sampel y.Dalam menganalisa data dengan menggunakan SPSS diperlukan suatu langkah-langkah yang harus dilakukan yakni : memasukkan data ke SPSS, mengisi data, menyimpan data, mengolah data, menyimpan hasil output, dan output SPSS dan analisasnya. 


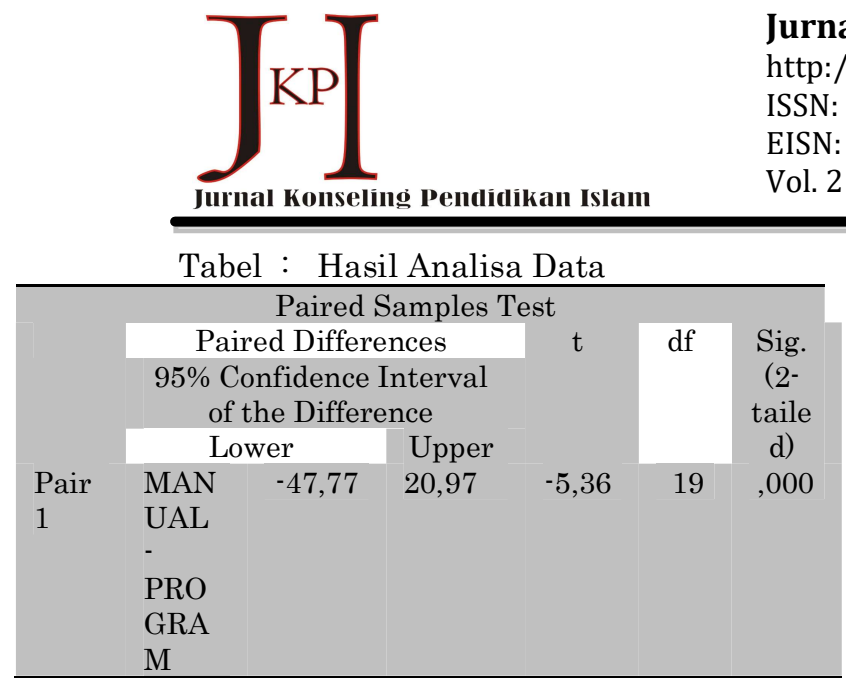

Sumber : Hasil analisa data menggunakan SPSS Paired Samples Ttest.

Sebagaimana dalam anggapan awal yang menyatakan belum adanya model program aplikasi intrumentasi data arah peminatan peserta didik yang dapat membantu kerja/tugas Guru Bimbingan dan Konseling. Sehingga dikembangkan program aplikasi instrumentasi data arah peminatan peserta didik ini agar kinerja Guru Bimbingan dan Konseling dapat ditingkatkan dalam memberikan layanan pada peserta didik.Maka dari hasil analisa tersebut di atas, jika Sig > 0,05 maka Ho diterima, dan jika Sig < 0,05 maka Ho ditolak.

Dengan berdasarkan hasil hitungini, dengan signifikansi kurang dari $5 \%$ maka dapat diinterpretasikan bahwa Ho ditolak. Dengan ditolaknya Ho, maka ada perbedaan kinerja tanpa dan dengan menggunakan program aplikasi instrumentasi data untuk menggali arah peminatan peserta didik SMP di Pamekasan. Sehingga dapat dikatakan bahwa kinerja dapat ditingkatkan dengan menggunakan program aplikasi instrumentasi data untuk menggali arah peminatan peserta didik SMP kelas IX di Pamekasan.

Pengujian penggunaan program aplikasi instrumentasi data untuk menggali arah peminatan peserta didik kelas IX pada sampel yakni Guru
Bimbingan Konseling yang tergabung dalam Musyawarah Guru Bimbingan Konseling (MGBK) Kabupaten Pamekasan Tahun 2019-2020. Sampel tersebut merupakan pengguna sekaligus ahli di bidang ke-BK-an karena dianggap tahu persis apa dan bagaimana arah peminatan peserta didik yang dilaksanakan di sekolah. Dan hasil uji coba menunjukkan bahwa sistem kerja dengan menggunakan program aplikasi instrumentasi data arah peminatan peserta didik ternyata lebih baik dibandingkan dengan sistem kerja tanpa menggunakan program aplikasi instrumentasi data arah peminatan peserta didik.

Dengan adanya perbedaan yang signifikan tersebut, dikatakan bahwa penggunaan program aplikasi instrumentasi data untuk menggali arah peminatan peserta didik SMP kelas IX dapat dipakai untuk kegiatan Layanan Bimbingan Konseling di Kabupaten Pamekasan. Dari hasil pengujian terlihat bahwa kinerja dengan menggunakan program aplikasi instrumentasi arah peminatan peserta didik SMP kelas IX memiliki taraf signifikansi< 0,05 , sehingga penggunaan pengembangan program aplikasi instrumentasi data untuk menggali arah peminatan peserta didik kelas IX SMP di Pamekasan ini tidak perlu direvisi, namun adanya pengembangan-pengembangan dan penyempurnaan diwaktu mendatang. Sehingga program aplikasi instrumentasi data arah peminatan peserta didik ini dapat dipergunakan dalam kegiatan layanan bimbingan dan konseling khususnya satuan layanan pendukung aplikasi instrumentasi oleh Guru Bimbingan dan Konseling/Konselor kelas IX SMP di Pamekasan. 
SIMPULAN

Pengembangan

program

instrumentasi data untuk menggali arah peminatan peserta didik kelas IX SMP ini adalah sebuah aplikasi instrumentasi yang nantinya dapat dimanfaatkan oleh semua Guru Bimbingan dan Konseling, dan Guru Bimbingan dan Konseling di Kabupaten Pamekasan pada khususnya. Dengan pengembangan aplikasi instrumentasi ini tentunya akan menambah perlengkapan layanan pendukung di sekolah yang ada selama ini sehingga dapat membantu kerja/tugas sekaligus akan dapat meningkatkan kinerja Guru Bimbingan dan Konseling dalam pelaksanaan layanan arah peminatan peserta didik terutama dalam pembuatan Lembar Rekomendasinya.

Pengembangan

program instrumentasi data arah peminatan peserta didik kelas IX ini telah diuji cobakan penggunaannya kepada beberapa Guru Bimbingan dan konseling yang tergabung dalam Musyawarah Guru Bimbingan dan Konsling (MGBK) Kabupaten Pamekasan. Uji coba yang dilakukan oleh peneliti kepada subyek uji yakni bagaimana kinerja Guru Bimbingan Konseling dalam melaksanakan layanan arah peminatan dan pembuatan rekomendasinya tanpa dan dengan menggunakan program aplikasi instrumentasi data arah pemintan peserta didik. Pengujian pengembangan program instrumentasi arah peminatan peserta didik ternyata hasilnya cukup signifikan. Hal ini dapat dilihat setelah hasil uji coba tersebut dengan menggunakan analisa data SPSS Paired Samples T-test. Dari analisa tersebut menghasilkan Signifikansi kurang dari $5 \%$. Apabila Sig > 0,05 maka Ho diterima, dan jika Sig $<0,05$ maka Ho ditolak. Dengan hasil Sig < 0,05 sehingga dapat diinterpretasikan bahwa dengan ditolaknya Ho, maka kinerja dengan menggunakan program aplikasi instrumentasi data untuk menggali arah peminatan peserta didik SMP kelas IX lebih meningkat dibandingkan tanpa menggunakan program aplikasi instrumentasi arah peminatan peserta didik (kerja secara manual).

\section{DAFTAR PUSTAKA}

Achmad Rifai. 2010. Profesionalisasi Konselor (Dalam Materi BK Pendidikan dan Latihan Profesi Guru Kouta 2010). Universitas PGRI Adi Buana. Surabaya

Akhmad Sudrajat, Arah peminatan peserta didik, 2013, http://akhmadsudrajat.word.pre ss.com, diunduh hari Jumat, tanggal 26 Desember 2020, pukul 10.35 .

Dedy Febry, Pengembangan, 2014, www.academia.edu, diunduh hari Jumat, 26 Desember 2020, pukul 09.50.

Desy Anwar. 2003. Kamus Lengkap Bahasa Indonesia terbaru, Penerbit Amelia. Surabaya

Dirjen PMPTK. 2007. Rambu-Rambu Penyelenggaraan Bimbingan dan Konseling Dalam Jalur Pendidikan Formal (Naskah Akdemik). Jakarta

Gerald Corey, 2005, Teori dan Praktek Konseling \& Psikoterapi, PT. Refika Aditama. Bandung.

Hartono dan Boy Soedarmadji, 2009, Psikologi Konseling; University Press UNIPA, Surabaya.

Ifdil, Aplikasi Instrumentasi, 2007, http://konselingindonesia.com, diunduh hari Rabu, 24 Desember 2020, pukul 07.20.

Lampiran Peraturan Menteri Pendidikan Dan Kebudayaan Nomor 68 Tahun 2013 Tentang Kerangka Dasar Dan Struktur Kurikulum Sekolah Menengah 
Pertama/Madrasah

Tsanawiyah. Jakarta

Lampiran Peraturan Menteri

Pendidikan Dan Kebudayaan

Republik Indonesia Nomor 111

Tahun $2014 \quad$ Tentang

Bimbingan Dan Konseling pada

Pendidikan Dasar Dan

Pendidikan Menengah, 2014, Jakarta.

Lampiran IV Peraturan Menteri Pendidikan Dan Kebudayaan Republik

Nomor 81A Tahun 2013Tentang Implementasi Kurikulum Pedoman Umum Pembelajaran. Jakarta

Mastur. 2009. Need Assesment Melalui Aplikasi Instrumentasi DCM (Daftar Cek Masalah) Dengan Sistem Komputer, MGP SMP/MTs. Kabupaten Kudus.

Materi Diklat Peningkatan Kompetensi Guru BK/Konselor SMP, 2013, Pusat Pengembangan dan Pemberdayaan Pendidik dan Tenaga Kependidikan Pendidikan Jasmani dan Bimbingan Konseling, Jakarta.

Materi 4 Praktik Peminatan Peserta Didik SMP, Pusat Pengembangan Dan Pemberdayaan Pendidikan Dan Tenaga Kependidikan Bidang Pendidikan Jasmani Dan Bimbingan Koneling, 2013, Jakarta.

Modul 8,Penilaian Layanan Bimbingan dan Konseling, 2013, Pusat Pengembangan dan Pemberdayaan Pendidik dan Tenaga Kependidikan Pendidikan Jasmani dan Bimbingan Konseling. Jakarta

Sugiyono. 2012. Metode Penelitian Kuantitatif Kualitatif dan $R \&$ $D$, Penerbit Alfabeta. Bandung.

Sujarweni Wiratna. 2014. V SPSS untuk Penelitian. Penerbit Pustaka Baru Press. Yogyakarta
Sutijono. 2010. Pengembangan Profesionalitas Guru (Dalam Materi Umum Pendidikan dan Latihan Profesi Guru Kouta 2010). Universitas PGRI Adi Buana. Surabaya 